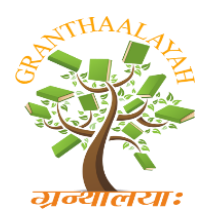

INTERNATIONAL JOURNAL OF RESEARCH GRANTHAALAYAH

A knowledge Repository

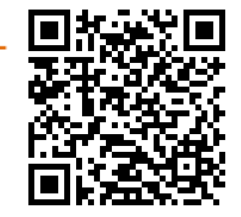

Science

\title{
USE OF ICT BASED LIBRARY RESOURCE AND SERVICES IN CONSTITUENT FIRST GRADE COLLEGES AFFILIATED TO UNIVERSITY OF MYSORE: STUDY
}

\author{
Dr. Chikkamanju ${ }^{* 1}$, Ambika $^{2}$, Hydar Ali $^{3}$ \\ ${ }^{* 1}$ Dos in Library and Information Science, University of Mysore-570006, INDIA \\ ${ }^{2,3}$ Research Scholar, Dos in Library and Information Science, University of Mysore-570006, \\ INDIA
}

\begin{abstract}
The study investigated the ICT based library and Information services in Constituent First Grade Colleges affiliated to University of Mysore.The present study demonstrates and elaborates the primary way to learn about ICTs, the purpose of using ICT enabled library services, to assess to what extent users are utilized ICT based library services and facilities, various aspects of Internet usage, favourite search engines, NLIST resources and services Suggestions have been given to make the service more beneficial in the library users.

The aims were to examine impacts of ICT on motivation and related issues such as learning outcomes, behaviour, and attendance and to quantify any impacts where possible. The study also set out to consider the ways in which ICT can best be used by under graduate students to enhance motivational impacts for pupils, especially for those disaffected with traditional forms of learning.

The present study aims to examine the ICT based library and Information services in Constituent First Grade Colleges affiliated to University of Mysore. The questionnaire method was adopted for the present study to collect the necessary data, keeping in view the objectives of the study. Total 236 questionnaires were distributed and 163 filled in questionnaires were collected back. The rate of response of $69.06 \%$. The collected data has been analysed using appropriate statistical techniques with SPSS such as chi-square test, mean and standard deviation for the analysis.

The majority mean value of 3.28 SD being 1.66 I read e-Books of respondents110(67.48\%) of students opine as 'Excellent', with a mean value of 1.59 and SD being 1.00. for Preferred search engine 20(12.26\%) respondents use 'Annual Reviews' Use of N-List resources and Services

From the analysis, it showed that our colleges should always embark on strategies towards adding more value to their ICT based library services. ICT based library services awareness program should be rendered to the graduate students at the very point of enrolment into the graduate studies for this will help the students to - wards understanding the need of utilizing the library properly and also appreciate technology more in their lives.
\end{abstract}


Keywords:

ICT Library Resources, Services, First Grade Colleges.

Cite This Article: Dr. Chikkamanju, Ambika, and Hydar Ali, "USE OF ICT BASED LIBRARY RESOURCE AND SERVICES IN CONSTITUENT FIRST GRADE COLLEGES AFFILIATED TO UNIVERSITY OF MYSORE: STUDY” International Journal of Research Granthaalayah, Vol. 4, No. 4 (2016): 42-48.

\section{INTRODUCTION}

Information as studies have shown is the act of acquiring knowledge. It is an important tool for a societal development and advancement. Alakpodia (2010) opined that one of the bases of accessing a country as developed is the extent to which its information system is enhanced to improve its socio-economic growth. The creation of institutional libraries, have strengthened and improve quality of learning, teaching and research in our various institutions. An institution without a library is like a dead duck. Library can be said to be an institutional tool used to emblaze teaching, learning and research in any institution. Haruna and Oyelekan (2010) opined that "academic libraries are meant to enhance access to variety of information resources and range of services. The integration of Information and Communication Technology (ICT) in library in the 1960s did not only add flavour in library activities such as shelving, arrangements, easy assessment etc. but also globalized the use of library resource.

The concept of ICT has transformed the world in all aspect of lives include the libraries and studies have also shown that for an effective library service in this modern age, the use of information and communication technology should be integrated in its service. In relation to this, it has become a necessity for all libraries to adopt and harness from the good deeds ICT has brought to the library services and academic research as a whole.

\section{OBJECTIVES OF THE STUDY}

- To investigate the level of use of NLIST resources and services to under graduate students

- To look at the purpose of visit the library

- To investigate the level of satisfaction in using the ICT based services as being rendered by the institution to the under graduate students

\section{DATA ANALYSIS AND INTERPRETATION}

Data analysis and interpretation have been framed and tested table- 1 to Table- 6 has given below

Table 1: Distribution of the questionnaire among respondents

\begin{tabular}{|l|l|l|l|}
\hline Name of the Colleges & $\begin{array}{l}\text { Questionnaire } \\
\text { distributed }\end{array}$ & $\begin{array}{l}\text { Questionnaire } \\
\text { Received }\end{array}$ & Percentage \\
\hline Maharaja's college & 126 & 89 & 70.63 \\
\hline
\end{tabular}




\begin{tabular}{|l|l|l|l|}
\hline Yuvaraja's College & 110 & 73 & 66.36 \\
\hline Total & 236 & 163 & 69.06 \\
\hline
\end{tabular}

The college wise details of the questionnaire distributed, received and number of students using ICT Based Library resource and services constituent first grade colleges are indicated table-1. A total questionnaire 236 were distributed among the students of first grade colleges affiliated to University of Mysore, Mysore of which 163 filled up questionnaire were received back consisting of $69.06 \%$ responses. The highest number of questionnaire has been received from the Maharaja's college $70.63 \%$ followed by Yuvaraja's College 66.36\% students.

Table 2: Purpose of visit the College Library

\begin{tabular}{|l|l|l|}
\hline Purpose of Visit & Respondents & Percentage \\
\hline To study & 28 & 17.18 \\
\hline To use library equipment & 33 & 20.25 \\
\hline $\begin{array}{l}\text { To barrow are return } \\
\text { books }\end{array}$ & 15 & 9.20 \\
\hline To access E-resources & 31 & 19.02 \\
\hline Reading news paper & 24 & 14.72 \\
\hline To use internet & 27 & 16.56 \\
\hline Any others & 5 & 3.07 \\
\hline $\begin{array}{l}\text { Chisquare }=24.485 \text { df6. } \mathrm{P}=0.0000 \\
\text { Yates chisquare-square= 23.278 Yates } \\
\mathrm{P}=0.0007\end{array}$ & Significant \\
\hline
\end{tabular}

Table-2 also indicates that $20.25 \%$ respondents visit the purpose of use of to use library equipment followed by $19.02 \%$ respondents visit the purpose of use to access E-resources, about $17.18 \%$ respondents from purpose of visit the library to study and 3.07\% respondents visit to the library for any other purposes.

The chi-square test was conducted 24.485 df6. $\mathrm{P}=0.0000$ less than 0.05 are accepted. The significant relationship between purpose of visit and parameters. And Yates chi-square $=23.278$ Yates $\mathrm{P}=0.0007$ are significant

Table 3: Purpose of use of Internet

\begin{tabular}{|l|l|l|l|l|l|l|l|}
\hline $\begin{array}{l}\text { Purpose of use } \\
\text { of Internet }\end{array}$ & Excellent & $\begin{array}{l}\text { Very } \\
\text { Good }\end{array}$ & Good & Average & Poor & Mean & SD \\
\hline $\begin{array}{l}\text { I read online } \\
\text { news }\end{array}$ & $49(28.22)$ & $41(25.15)$ & $32(19.63)$ & $33(20.24)$ & $08(04.07)$ & 2.45 & 1.24 \\
\hline $\begin{array}{l}\text { I read Online } \\
\text { Magazines }\end{array}$ & $33(20.24)$ & $16(09.81)$ & $74(45.39)$ & $10(06.13)$ & $30(18.40)$ & 2.93 & 1.3 \\
\hline I read e-Books & $42(25.76)$ & $18(11.04)$ & $19(11.65)$ & $20(12.26)$ & $64(39.26)$ & 3.28 & 1.66 \\
\hline I read e-journals & $68(41.71)$ & $24(14.73)$ & $17(10.42)$ & $23(14.11)$ & $31(19.01)$ & 2.54 & 1.58 \\
\hline I read e-mail & $23(14.11)$ & $68(41.71)$ & $55(33.74)$ & $14(08.58)$ & $3(01.84)$ & 2.42 & 0.9 \\
\hline
\end{tabular}




\begin{tabular}{|l|l|l|l|l|l|l|l|}
\hline $\begin{array}{l}\text { I read job } \\
\text { information }\end{array}$ & $45(27.60)$ & $54(33.12)$ & $15(09.20)$ & $42(25.76)$ & $7(04.29)$ & 2.46 & 1.25 \\
\hline $\begin{array}{l}\text { I read movie } \\
\text { review }\end{array}$ & $15(09.20)$ & $27(16.56)$ & $58(35.58)$ & $46(28.22)$ & $17(10.42)$ & 3.14 & 1.1 \\
\hline
\end{tabular}

The Table-3. Depicts that in case of Purpose of use of Internet 'I read online news' about 49(28.22\%) of students opine as 'Excellent', followed by I read Online Magazines 74(45.39\%) opine as 'Good', of students opine as 'I read e-Books' 64(39.26\%) opine as 'Poor', with a mean value of 3.28 and SD being 1.66 followed by 'I read e-journals' 68(41.71) opine as 'Excellent', of students opine as 'I read e-mail' 68(41.71\%) opine as 'Very Good', of students opine 'as I read job information' $54(33.12 \%)$ opine as 'Very Good', of students opine 'I read movie review' $58(35.58 \%)$ opine as 'Good', mean value of 3.14 and SD being 1.1 .

Table 4: Preferred search engine

\begin{tabular}{|l|l|l|l|l|l|l|l|}
\hline $\begin{array}{l}\text { Search } \\
\text { Engine }\end{array}$ & Excellent & $\begin{array}{l}\text { Very } \\
\text { Good }\end{array}$ & Good & Average & Poor & Mean & SD \\
\hline Google & $110(67.48)$ & $25(15.33)$ & $14(08.58)$ & $12(07.36)$ & $2(01.22)$ & 1.59 & 1.00 \\
\hline Yahoo & $99(60.73)$ & $33(20.24)$ & $9(05.52)$ & $21(12.88)$ & $1(00.61)$ & 1.72 & 1.08 \\
\hline MSN & $58(35.58)$ & $24(14.72)$ & $42(25.76)$ & $28(17.17)$ & $11(06.74)$ & 2.45 & 1.31 \\
\hline Alta Vista & $55(33.74)$ & $43(28.38)$ & $14(08.58)$ & $46(28.22)$ & $5(03.06)$ & 2.40 & 1.29 \\
\hline Hot Bot & $21(12.88)$ & $25(15.33)$ & $45(27.60)$ & $31(19.01)$ & $41(25.15)$ & 3.28 & 1.34 \\
\hline InfoSeek & $14(08.58)$ & $20(12.26)$ & $66(40.49)$ & $45(27.60)$ & $18(11.04)$ & 3.20 & 1.07 \\
\hline Inktomi & $26(15.95)$ & $50(30.67)$ & $44(26.99)$ & $32(19.63)$ & $11(06.74)$ & 2.71 & 1.15 \\
\hline
\end{tabular}

The Table-4 Depicts that in case of Preferred search engine 'Google' about 110(67.48\%) of students opine as 'Excellent', with a mean value of 1.59 and SD being 1.00. followed by Yahoo ' $99(60.73 \%)$ of students opine as MSN 58(35.58\%) opine as 'Excellent', of students opine as Alta Vista 42 55(33.74\%) opine as 'Excellent', of students opine as Hot Bot 45(27.60\%) opine as 'Excellent', mean value of 3.28 and SD being 1.34. of students opine as InfoSeek 66(40.49\%) opine as 'Good', mean value of 3.20 and SD being 1.07. of students opine as Inktomi 50(30.67\%) opine as Very Good.

Table 5: Use of N-List resources and Services

\begin{tabular}{|l|l|l|}
\hline E-journals & Respondents & Percentage \\
\hline American Institute of Physics & 07 & 04.29 \\
\hline American Physical Society & 01 & 00.61 \\
\hline Annual Reviews & 20 & 12.26 \\
\hline Cambridge University Press & 18 & 11.04 \\
\hline Economic and Political Weekly & 01 & 00.61 \\
\hline Indian Journals & 14 & 08.58 \\
\hline Institute of Physics & 13 & 07.97 \\
\hline JSTOR & 09 & 05.52 \\
\hline Oxford University Press & 01 & 00.61 \\
\hline Royal Society of Chemistry & 09 & 05.52 \\
\hline H. W. Wilson & 08 & 04.07 \\
\hline
\end{tabular}




\begin{tabular}{|l|l|l|}
\hline E-books & & \\
\hline Cambridge Books Online & 08 & 04.07 \\
\hline E-brary & 06 & 03.68 \\
\hline EBSCoHost-Net Library & 10 & 06.13 \\
\hline Hindustan Book Agency & 05 & 03.06 \\
\hline $\begin{array}{l}\text { Institute of South East Asian } \\
\text { Studies(ISEAS) Books }\end{array}$ & 04 & 02.45 \\
\hline Oxford Scholarship & 06 & 03.68 \\
\hline Springer eBooks & 02 & 01.22 \\
\hline Sage Publication eBooks & 02 & 01.22 \\
\hline Taylor Francis eBooks & 02 & 01.22 \\
\hline Myilibrary-McGraw Hill & 01 & 00.61 \\
\hline $\begin{array}{l}\text { E-resources for Universities } \\
\text { (Web of science) }\end{array}$ & 14 & 08.05 \\
\hline $\begin{array}{l}\text { Bibliographical databases } \\
\text { (MathSciNet) }\end{array}$ & 02 & 01.22 \\
\hline
\end{tabular}

Table-5 reveals' that majority of 20(12.26\%) 'Annual Reviews' Use of N-List resources and Services followed by 'Cambridge University Press' about 18(11.04\%) $08.05 \%$ of 'E-resources for Universities( Web of science)' and 'Indian Journals' about 07.97\% Institute of Physics', 06.13\% of 'EBSCoHost-Net Library' and least 00.61\% 'American Physical Society'.

Table 6: Rating of N-LIST resources and services based on their features

\begin{tabular}{|c|c|c|c|c|c|c|c|}
\hline Features & Excellent & Very Good & Good & Average & Poor & Mean & SD \\
\hline Easy to use & $86(52.76)$ & $21(12.88)$ & $18(11.04)$ & $31(19.01)$ & $7(4.29)$ & 2.09 & 1.33 \\
\hline Up-to-date & $10(06.13)$ & $34(20.85)$ & $29(15.95)$ & $55(33.74)$ & $12(07.36)$ & 3.18 & 1.11 \\
\hline Accessibility & $31(19.01)$ & $39(23.92)$ & $12(07.36)$ & $26(15.95)$ & $33(20.24)$ & 2.94 & 1.51 \\
\hline Access Speed & $33(20.24)$ & $42(25.76)$ & $31(19.01)$ & $10(06.13)$ & $15(09.29)$ & 2.48 & 1.26 \\
\hline Usefulness & $51(31.28)$ & $15(09.29)$ & $17(10.42)$ & $41(25.15)$ & $29(17.79)$ & 2.88 & 1.56 \\
\hline $\begin{array}{l}\text { Hypertext } \\
\text { links }\end{array}$ & $26(15.95)$ & $21(12.88)$ & $18(11.04)$ & $31(19.01)$ & $57(34.96)$ & 3.47 & 1.51 \\
\hline $\begin{array}{l}\text { Organized } \\
\text { information }\end{array}$ & $10(06.13)$ & $34(20.85)$ & $29(17.79)$ & $55(33.74)$ & $12(07.36)$ & 3.18 & 1.11 \\
\hline $\begin{array}{l}\text { Comprehensiv } \\
\text { eness }\end{array}$ & $31(19.01)$ & $39(23.92)$ & $12(07.36)$ & $26(15.95)$ & $33(20.24)$ & 2.94 & 1.51 \\
\hline Flexibility & $33(20.24)$ & $42(25.76)$ & $31(19.01)$ & $10(06.13)$ & $15(09.29)$ & 2.48 & 1.26 \\
\hline
\end{tabular}

The Table-6. Depicts that in case of 'Easy to use' about 86 (52.76\%) of students opine as 'Excellent', mean value of 2.09 and SD being 1.33. followed by Up-to-date '55(33.74\%) of students opine as Average Accessibility 39(23.92\%) opine as 'Very Good', of students opine as Average Access Speed 42 42(25.76\%) opine as 'Very Good', of students opine as Average Usefulness 51(31.28\%) opine as 'Excellent', of students opine as Average Hypertext links $57(34.96 \%)$ opine as 'Poor', mean value of 3.47 and SD being 1.51. followed by Organized information 55(33.74\%) opine as 'Average', mean value of 3.18 and SD being 1.11. followed by Comprehensiveness 39(23.92\%) opine as 'Very Good', of students opine as Average Flexibility $42(25.76 \%)$ opine as 'Very Good'. 
Table 7: Extent of Dependency on College Library to Fulfill Information Requirement respondents.

\begin{tabular}{|l|l|l|}
\hline $\begin{array}{l}\text { Extent } \\
\text { Dependency }\end{array}$ & Respondents & Percentage \\
\hline To great extent & 81 & 49.69 \\
\hline To moderate extent & 32 & 19.63 \\
\hline To a little extent & 45 & 27.60 \\
\hline Not at all & 5 & 03.06 \\
\hline Total & 163 & 100.00 \\
\hline
\end{tabular}

The Table-7 Depicts that out of 163 respondents 81 (49.69\%) of respondents related to Extent of Dependency on College Library to fulfill Information Requirement opine as To great extent followed by $45(27.60 \%)$ 'To a little extent' and 32(19.63\%)' To moderate extent dependency on College Library.

\section{RESULTS AND DISCUSSIONS}

1. The highest number of questionnaire has been received from the Maharaja's college $70.63 \%$ followed by Yuvaraja's College $66.36 \%$ students.

2. $20.25 \%$ respondents visit the purpose of use of to use library equipment followed by $19.02 \%$ respondents visit the purpose of use to access E-resources

3. $86(52.76 \%)$ of students opine as 'Excellent', mean value of 2.09 and SD being 1.33. Rating of N-LIST resources and services

4. (49.69\%) of respondents related to Extent of Dependency on College Library to fulfill Information Requirement

\section{CONCLUSIONS \& RECOMMENDATIONS}

The integration of ICT can promote significant changes in the practices of teaching and learning and is beneficial for students, In this study, the respondents reported that their teachers sometimes use ICT during lecture. Keeping the importance of ICT in view, the study concluded that teachers should make maximum use of ICT during their lecture because it has a great impact on student's learning. Majority of the respondents admitted that they use internet for study but they do not know about advance searching techniques. this study also strongly recommends that students should be trained to use advance searching techniques for retrieving the material of their interests. in their study reported that the vast majority of the participants used Internet search engines rather than specialized databases and full-text resources. Findings of this study also reflect similar result. Result showed that the Google is the most used search engine by the respondents. The study found that the available PCs in computer labs are inadequate for meeting the needs of student and they feel problem in accessing computers. It is recommended that the number of PCs should be increased. It was also found that the students of education faculty do not know about the use of electronic books. It is highly recommended that they should be trained in using electronic books, journals and open access databases relevant to their field. The current study confirms the findings of Swain (2010), Ndinoshiho (2010), Crawford (2003), Togia \& Tsigilis (2010) and Ozoemelem (2009). 


\section{REFERENCES}

[1] Alakpodia O.N Assessment of information literacy skills among librarians in Delta State University, Abraka. An International Journal of Information and Communication Technology. 2010, 7(1). 55-63.

[2] Haruna, I and Oyelekan, G. O. Provision and Utilisation of Information Resources and Services in Nigerian Defence Academy (NDA) Library, Kaduna. An International Journal of Information and Communication Technology. 2010, 7(1). 11-18.

[3] http://webarchive.nationalarchives.gov.uk/20130401151715/http://www.education.gov.uk /publications/eOrderingDownload/DfES-0794-2003.pdf

[4] Islam S and Islam N. Information and Communication Technology (ICT) in Libraries: A New Dimension in Librarianship. Asian Journal of Information Technology. 2006,5(8). 809-817.

[5] Mohamed H.K Use of ICT based resources and services in special libraries in kerala. Annals of Library and Information Studies. 2007, Vol 54, 23-31.

[6] Ozoemelem, O. AUse of electronic resources by postgraduate students of the department of Library and Information of Delta State University, Nigeria. Library Philosophy and Practice. Available: http://unllib.unl.edu/LPP/obuh-alex.htm

[7] Satpathy S.K, Maharana R.K and Panda S.K.. Use of Information Communication Technology (ICT) Based Services by Faculty members and Students of One Premier Engineering College of Odisha. International Journal of Digital Library Services. 2012, 2(3). 76-91.

[8] Shakeel Ahmad Khan, Rubina Bhatti., Aqeel Ahmad Khan.Use of ICT by Students: A Survey of Faculty of Education at IUB, http://unllib.unl.edu/LPP/Library Philosophy and Practice 2011

[9] Shuva N.Z, Banerjee T, Naningrum A, Madrid M, Agabirwe P and Kulisooma E ICTs in national libraries of Bangladesh Indonesia, Philippines and Uganda: comparative study. INFOtheca - Journal of Informatics \& Librarianship. 2011, 12(1). 33-44.

[10] A.K, Munshi M.N, Sayeed M.A The adoption of information and communication technology (ICT) in the university libraries of Bangladesh: An exploratory study. International Seminar "Vision 2021: the role of libraries for building digital Bangladesh”. 2011, 154

[11] Swain, D.K. Students keenness on use of e-resources. Electronic Library 2010, 28(4), 580-591

[12] Togia, A. \& Tsigilis, N. Awareness and use of electronic information resources by education graduate students: preliminary results from the Aristotle University of Thessaloniki. Retrieved October, 201. 